\title{
Detailed FT near-infrared study of the behaviour of water and hydroxyl in sedimentary length-fast chalcedony, $\mathrm{SiO}_{2}$, upon heat treatment
}

\author{
Patrick Schmidt*, Aïcha Badou, François Fröhlich \\ Muséum national d'histoire naturelle, Dpt. de Préhistoire UMR 7194, Centre de spectroscopie infrarouge CP 57, 57, rue Cuvier 75231, Paris Cedex 05, France
}

\section{A R T I C L E I N F O}

\section{Article history:}

Received 6 February 2011

Received in revised form 28 April 2011

Accepted 20 June 2011

\section{Keywords:}

Length-fast chalcedony

Flint

Surface silanole $\mathrm{SiOH}$

Porosity

Microstructure

\begin{abstract}
A B S T R A C T
Chalcedony is a porous spatial arrangement of hydroxylated nanometre sized $\alpha$-quartz $\left(\mathrm{SiO}_{2}\right)$ crystallites. Due to micro-structural transformations upon heat treatment, the optical and mechanical properties of the rock are modified. We investigated these transformations in sedimentary length-fast chalcedony through Fourier Transform near- and mid-infrared spectroscopy using direct transmission and the reflectivity. Chemical adsorption potential and absorption of $\mathrm{H}_{2} \mathrm{O}$ by pores was studied after heat treatment. We found that water held in open porosity is reduced upon heat treatment to temperatures above $150^{\circ} \mathrm{C}$. Silanole is noticeably lost from 250 to $300^{\circ} \mathrm{C}$ upwards and new bridging Si-O-Si further reduces the surface of open pores, creating a less porous material. Molecular water, resulting from the reaction $\mathrm{Si}-\mathrm{OH}$ $\mathrm{HO}-\mathrm{Si} \rightarrow \mathrm{Si}-\mathrm{O}-\mathrm{Si}+\mathrm{H}_{2} \mathrm{O}$ creates new isolated pores within the material. At temperatures above $500^{\circ} \mathrm{C}$, the samples start internal fracturing, permitting water held in isolated pores to be evacuated. These results shed light on thermal transformations in chalcedony and allow for a better understanding of mechanical transformations after heat treatment.
\end{abstract}

(c) 2011 Elsevier B.V. All rights reserved.

\section{Introduction}

Chalcedony consists of a spatial arrangement of $50-100 \mathrm{~nm}$ measuring $\alpha$-quartz crystallites [1]. The crystallites align in fibres ranging up to several millimetres or even centimetres in well crystallised specimens. Based on orientation of the crystallites within these fibres, several authors have distinguished different types of chalcedony [2-4]. The most common type in nature is length-fast chalcedony with an orientation of the quartz $c$-axis perpendicular to the fibre axis (referred to as chalcedony hereafter) [2]. Flint typically consists of length-fast chalcedony with shorter and somewhat less organised fibres that are not easy to discern under the polarised light microscope. Crystallographic studies have shown that the crystallites forming chalcedony fibres are polysynthetic twins according to the Brazil law on a very small scale $[3,5]$. Studies concerning the water content of chalcedony [6-9] show up to $2 \mathrm{wt} \%$ of total water. These works subdivide the total water content into molecular water $\mathrm{H}_{2} \mathrm{O}$ and silanole $\mathrm{SiOH}$. Molecular water in chalcedony is mainly adsorbed in pores and interstices [6], a part of which may be interconnected to form a network of open or closed porosity. The crystallite surface at the walls of open pores is covered with silanole, forming hydrogen bonds (H-bonds) with each other and with molecular water held in the vicinity of the grain boundaries [7]. Twin interfaces are another

\footnotetext{
* Corresponding author. Tel.: +33 634281896.

E-mail address: schmidt@mnhn.fr (P.Schmidt).
}

site where surface silanole can be expected [7]. A third type of hydroxyl is structural silanole that compensates free charges due to impurities and defects in the quartz lattice [8]. The concentration of structural silanole, however, was shown to be insignificant in chalcedony [6]. Due to the strong polar nature of the $\mathrm{OH}$ bond, infrared spectroscopy is a convenient and frequently used means of studying water related defects in quartz and chalcedony [8,10-13]. Fundamental vibrations of silanole and molecular water cause a broad absorption in the mid infrared at $\approx 3400 \mathrm{~cm}^{-1}$ that interferes with the $\mathrm{OH}$ stretching vibration of silanole $[8,11]$. The $\mathrm{SiOH}$ combination mode, involving $\mathrm{O}-\mathrm{H}$ stretching and $\mathrm{Si}-\mathrm{O}-\mathrm{H}$ bending, causes a band in the near-infrared (NIR) between 4600 and $4300 \mathrm{~cm}^{-1}$ [14]. $\mathrm{H}_{2} \mathrm{O}$ is individualised through a $\left(v_{2}+v_{3}\right)$ combination band around $5200 \mathrm{~cm}^{-1}$ and the first overtone of the stretching vibration at $7000 \mathrm{~cm}^{-1}[14,15]$. The shapes of the combination bands of water and silanole are sensitive to hydrogen bonding. The $\mathrm{SiOH}$ absorption shifts to lower wavenumbers when silanole is involved in H-bonding with neighbouring silanoles or molecular water [6,7,15]. Langer and Flörke [15] identified two types of $\mathrm{SiOH}$ in opals and showed the combination band to be a convolution of a high energy component, free from $\mathrm{H}$-bonding, and a low energy component, representing hydrogen bonded silanole. The fundamental $\mathrm{OH}$ stretching vibration frequency is also sensitive to hydrogen bonding and the band shifts between $3750 \mathrm{~cm}^{-1}$ for isolated- and $3500 \mathrm{~cm}^{-1}$ for strongly H-bonded groups [16-18]. Isolated $\mathrm{SiOH}$ in chalcedony, not or almost not involved in hydrogen bonding, can be measured through an $\mathrm{OH}$ stretching band at $3740 \mathrm{~cm}^{-1}[7,8,17,19]$. 
Table 1

Samples, description and thicknesses ( $C=$ concentration before annealing as determined by the NIR absorption in the hydrated state).

\begin{tabular}{|c|c|c|c|c|c|}
\hline Sample & Description & No. of samples & Thickness & $\mathrm{C} \mathrm{SiOH} \mathrm{[wt \% ]}$ & $\mathrm{C} \mathrm{H}_{2} \mathrm{O}[\mathrm{wt} \%]$ \\
\hline SB-Cal-07 & Length-fast chalcedony from an agate geode. & 7 & $670 \pm 10 \mu \mathrm{m}$ & 0.31 & 0.61 \\
\hline SB-Cal-06 & Length-fast chalcedony from an agate geode. & 1 & $720 \pm 10 \mu \mathrm{m}$ & 0.32 & 0.56 \\
\hline PS-S-02 & $\begin{array}{l}\text { Turonian fine flint, consisting of length-fast } \\
\text { chalcedony. East of Tours, France. }\end{array}$ & 2 & $705 \pm 5 \mu \mathrm{m}$ & 0.50 & 0.66 \\
\hline PS-09-04 & Coniacian black flint, Étretat, France. & 1 & $545 \pm 5 \mu \mathrm{m}$ & 0.58 & 0.73 \\
\hline PS-09-07 & $\begin{array}{l}\text { Santonian grey flint from dedolomised chalk } \\
\text { level, cliffs of Étretat, France. }\end{array}$ & 1 & $1037 \pm 5 \mu \mathrm{m}$ & 0.45 & 0.45 \\
\hline PS-09-11 & Turonian black flint, cliffs of Étretat, France. & 1 & $997 \pm 5 \mu \mathrm{m}$ & 0.63 & 0.56 \\
\hline PS-09-13 & $\begin{array}{l}\text { Turonian black flint with grey cortex, cliffs of } \\
\text { Étretat, France. }\end{array}$ & 1 & $556 \pm 5 \mu \mathrm{m}$ & 0.6 & 0.59 \\
\hline PS-09-14 & Turonian black flint, cliffs of Étretat, France. & 1 & $538 \pm 5 \mu \mathrm{m}$ & 0.5 & 0.71 \\
\hline PS-09-15 & $\begin{array}{l}\text { Turonian brown flint, north of Le grand } \\
\text { Pressigny, France. }\end{array}$ & 1 & $982 \pm 5 \mu \mathrm{m}$ & 0.75 & 0.75 \\
\hline PS-09-24 & $\begin{array}{l}\text { Turonian brown to ochre flint, Le grand } \\
\text { Pressigny, France. }\end{array}$ & 1 & $995 \pm 5 \mu \mathrm{m}$ & 0.55 & 0.61 \\
\hline PS-09-25 & $\begin{array}{l}\text { Upper Cretaceous brown flint, Le grand } \\
\text { Pressigny, France. }\end{array}$ & 1 & $998 \pm 5 \mu \mathrm{m}$ & 0.72 & 0.74 \\
\hline PS-09-38 & $\begin{array}{l}\text { Upper Cretaceous light grey flint containing } \\
\text { lutécite. From detritic sand deposit, north of Le } \\
\text { grand Pressigny, France. }\end{array}$ & 1 & $1050 \pm 5 \mu \mathrm{m}$ & 0.6 & 0.73 \\
\hline PS-09-41 & $\begin{array}{l}\text { Turonian brown to ochre flint, Le grand } \\
\text { Pressigny, France. }\end{array}$ & 1 & $549 \pm 5 \mu \mathrm{m}$ & 0.61 & 0.67 \\
\hline
\end{tabular}

In a previous study, Schmidt and Fröhlich [20] showed that the thermal evolution of the mid infrared absorption band at $555 \mathrm{~cm}^{-1}$ can be used for evaluating the formation of new bridging $\mathrm{Si}-\mathrm{O}-\mathrm{Si}$ after the evacuation of $\mathrm{Si}-\mathrm{OH}$ from chalcedony. The disappearance of the band at temperature above $300^{\circ} \mathrm{C}$ is due to recrystallisation resulting from heat treatment.

Based on the infrared signature of water in chalcedony, we present here new data on the process of 'dehydration' of chalcedony upon heat treatment. The work was undertaken in order to shed light on micro-structural transformations when the rock is subjected to heat treatment. The study gives new insight into thermal response, structural changes at the crystallite boundaries and the evolution of porosity.

\section{Samples and experimental}

11 samples of flint from different origins in the Paris Basin (France), all consisting of sedimentary length-fast chalcedony, and two samples of agate of unknown provenience, consisting of hydrothermal length-fast chalcedony, were analysed. Sample numbers and descriptions are resumed in Table 1. All samples were cut into sections with thicknesses between 600 and
$1100 \mu \mathrm{m}$ and diamond polished on both sides. The transmission was measured at normal incidence between 5600 and $3000 \mathrm{~cm}^{-1}$ with a resolution of $8 \mathrm{~cm}^{-1}$, using a Brucker Vector 22 FTIR spectrometer and unpolarised radiation. A circular aperture of $12 \mathrm{~mm}$ diameter delimited the analysed area on the slabs. The baseline for absorbance measurements of the two combination bands was a straight line between the two lowest points on either side of the absorption bands (Fig. 1a). The baseline for the absorbance measurements of isolated $\mathrm{SiOH}$ at $3740 \mathrm{~cm}^{-1}$ is shown in Fig. 1b. Error bars for the measured absorptions were calculated by repeating spectral acquisition 30 times on one sample.

The quantitative determination of the silanole and molecular water contents was calculated, using the molar absorption coefficients given by Scholze [14]. $\mathrm{H}_{2} \mathrm{O}$ concentration was determined through the linear absorption coefficient $\alpha=1.14 \mathrm{~L} / \mathrm{mol} \mathrm{cm}$, measured at $5430 \mathrm{~cm}^{-1}$. Due to morphology changes of the $\mathrm{SiOH}$ combination band upon heat treatment, the silanole concentration was calculated with the integral absorption coefficient $\alpha=160 \mathrm{~L} / \mathrm{mol} \mathrm{cm}^{2}$.

Mid infrared reflectance data at $555 \mathrm{~cm}^{-1}$ was collected on the polished surfaces of the 11 flint samples. Spectra were obtained between $600 \mathrm{~cm}^{-1}$ and $400 \mathrm{~cm}^{-1}$ with a resolution of $2 \mathrm{~cm}^{-1}$ on the
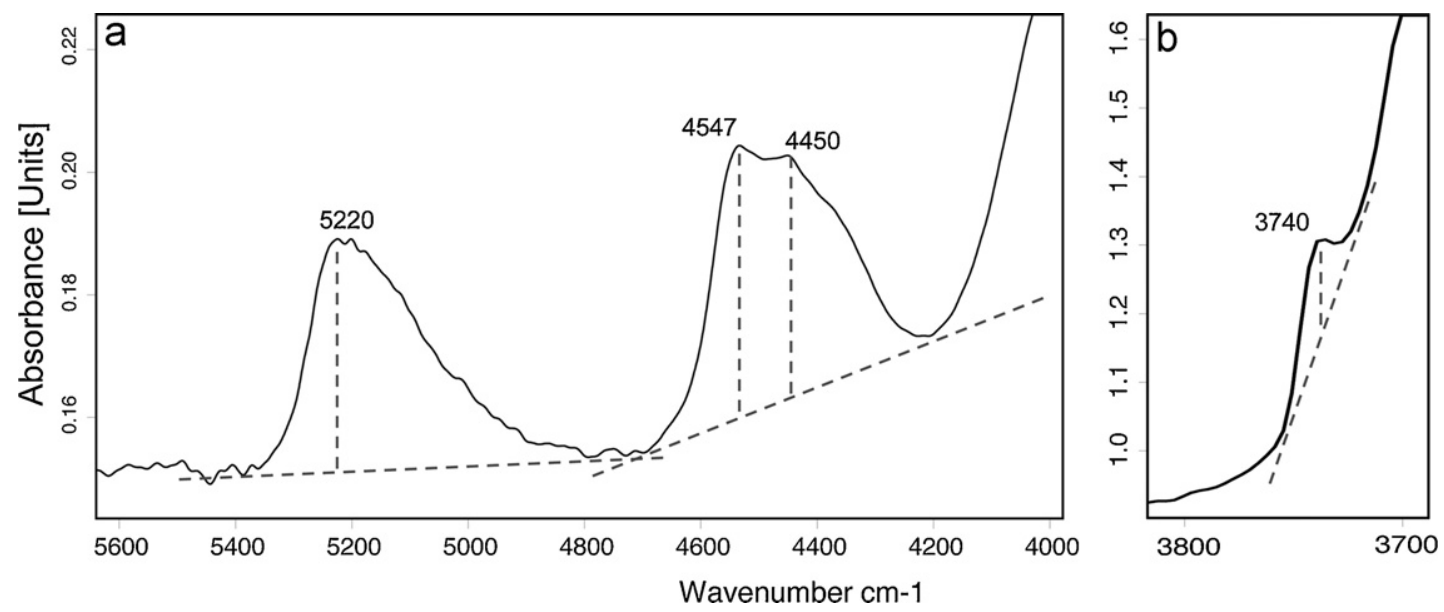

Fig. 1. Baselines used for the measurement of the absorbances that are referred to in the text. 
same spectrometer. The reflection coefficient $(R)$ was measured at $45^{\circ}$ with unpolarised radiation.

All samples underwent heat treatment in order to assess the thermal evolution of the different $\mathrm{OH}$ species. The annealing sequence was as follows. The samples were dehydrated at $110^{\circ} \mathrm{C}$ for $48 \mathrm{~h}$ in an electrical furnace. Spectra were recorded in the dry state immediately after the samples had cooled to room temperature. The samples were then rehydrated in deionised $\mathrm{H}_{2} \mathrm{O}$ for one night and a second spectrum was acquired in the hydrated state. After this, the samples were heated to $150^{\circ} \mathrm{C}$ for $6 \mathrm{~h}$ and the transmission was measured in the dry state immediately after the samples had cooled to room temperature. The samples were rehydrated in deionised $\mathrm{H}_{2} \mathrm{O}$ for one night and the transmission was measured in the rehydrated state. The samples were then heated to the next higher temperature and the measuring protocol was repeated. This sequence was continued with $50^{\circ} \mathrm{C}$ steps until $600^{\circ} \mathrm{C}$. The annealing temperatures were held for $6 \mathrm{~h}$. Ramp rates for each temperature step were chosen in order to prevent fracturing of the slabs. Rates varied from $20^{\circ} \mathrm{C} / \mathrm{min}$ for the low temperature steps and $0.2^{\circ} \mathrm{C} / \mathrm{min}$ for the $600^{\circ} \mathrm{C}$ heating step. All transmission measurements were acquired at room temperature.

In order to verify if this experimental protocol is representative of samples that are heated to a single temperature, the sample SB-Cal-07 was cut into 7 slabs. Two of these polished sections underwent the complete sequence and the 5 remaining sections were heated to single temperatures $\left(350^{\circ} \mathrm{C}, 400^{\circ} \mathrm{C}, 450^{\circ} \mathrm{C}, 500^{\circ} \mathrm{C}\right.$ and $550^{\circ} \mathrm{C}$ ) for control. These control samples permit to evaluate the difference between the heating of a single sample to successive temperatures and a sample heated to a single temperature. Additionally, two sections from samples SB-Cal-07 and PS-S-02 respectively underwent the complete annealing sequence but were held at the maximum temperature for different durations $(3 \mathrm{~h}$ and $6 \mathrm{~h}$ ). If the observed changes in the spectra are due to the maximum temperature of the heat treatment or the total time of annealing can be seen by the comparison between these control samples.

Due to technical problems, the samples heated to $200^{\circ} \mathrm{C}$ could not be analysed immediately after they had cooled to room temperature. Samples had time (approx. $30 \mathrm{~min}$ ) to adsorb small amounts of $\mathrm{H}_{2} \mathrm{O}$ from atmospheric humidity and yielded spectra of slightly rehydrated samples. The dehydrated state data for the $200{ }^{\circ} \mathrm{C}$ heating step is therefore missing. This experience shows the difficulty to maintain chalcedony samples in a dehydrated state after heat treatment.

\section{Results}

\subsection{NIR spectra}

Spectra of all samples show the expected $\mathrm{SiOH}$ combination band near $4500 \mathrm{~cm}^{-1}$ and the $\mathrm{H}_{2} \mathrm{O}$ combination band near $5220 \mathrm{~cm}^{-1}$. The sample's molecular water and silanole contents before annealing are: $0.59-0.75 \mathrm{wt} \% \mathrm{H}_{2} \mathrm{O}$ and $0.45-0.75 \mathrm{wt} \% \mathrm{SiOH}$. Upon heat treatment the samples show temperature dependent evolution of the two bands.

\subsubsection{Hydroxyl loss upon heat treatment}

3.1.1.1. Silanoles. The near infrared spectra of samples annealed to successive temperatures show the loss of silanole upon heat treatment. Fig. 2 shows the reduction of silanole, measured at $4547 \mathrm{~cm}^{-1}$, as a function of temperature for flint (Fig. 2a-c) and agate samples (Fig. 2d). The values plotted in Fig. 2 are extracted from spectra acquired on samples in their dehydrated state. The graphs show the silanole content of the samples to remain stable until $250^{\circ} \mathrm{C}$ within the limits of the calculated error. The silanole content is progressively reduced at temperatures higher than $300^{\circ} \mathrm{C}$. The rate of decrease slows down at approximately
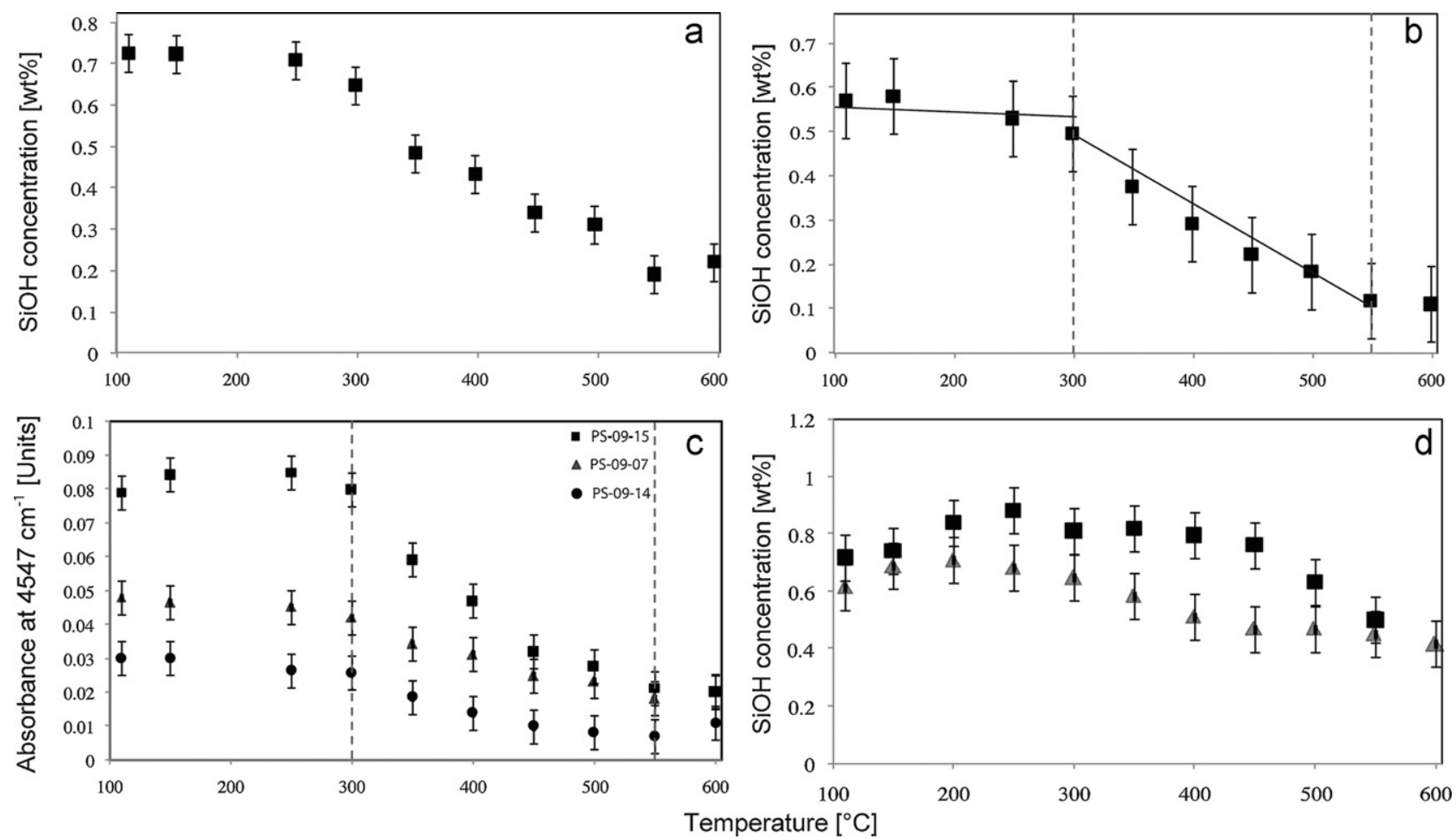

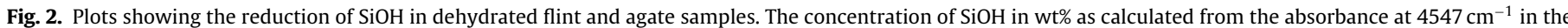

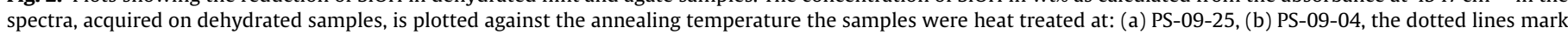

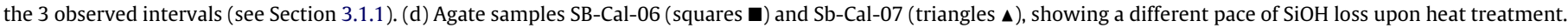
(c) Plot of the values of absorbance at $4547 \mathrm{~cm}^{-1}$ in dehydrated state spectra of PS-09-14/15/07, showing the 3 temperature intervals that are found in all flint samples. 

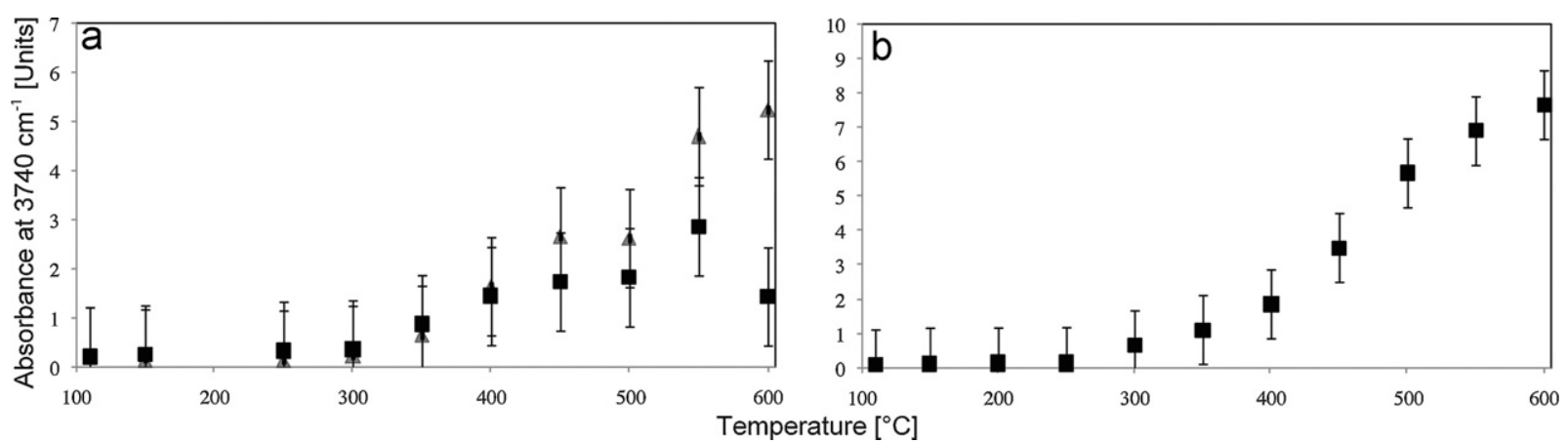

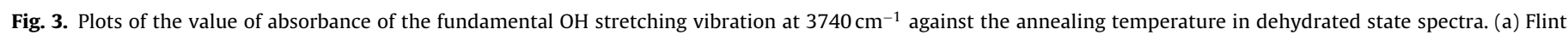
samples PS-09-07 ( $\mathbf{\square})$, PS-09-41 ( $\mathbf{\Delta}$ ). (b) Agate sample SB-Cal-07. The plots show that SiOH becomes more isolated from $300{ }^{\circ} \mathrm{C}$ upwards.

$550^{\circ} \mathrm{C}$ and the curves become flatter. These curves indicate the presence of three temperature intervals, (1) until $250-300^{\circ} \mathrm{C},(2)$ between $300^{\circ} \mathrm{C}$ and $550^{\circ} \mathrm{C}$ and (3) above $550^{\circ} \mathrm{C}$. The majority of the loss of silanole takes place between $300^{\circ} \mathrm{C}$ and $550^{\circ} \mathrm{C}$. The observed three intervals are found in all 11 flint samples. The plot of the integrated total area under the combination band as a function of temperature (Fig. 6a) shows the same three intervals. The agate samples show a somewhat different evolution of $\mathrm{SiOH}$ (Fig. 2d). Silanole is lost in these samples from $200^{\circ} \mathrm{C}$ to $250^{\circ} \mathrm{C}$ upwards but the three temperature intervals seen in flint are not observed.

The plots of the intensity of the fundamental $\mathrm{OH}$ stretching band of isolated $\mathrm{SiOH}$ groups at $3740 \mathrm{~cm}^{-1}$ (Fig. 3) show the increase of silanole not involved in hydrogen bonding. The values are extracted from spectra in the dehydrated state. The concentration of isolated $\mathrm{SiOH}$ increases from $300^{\circ} \mathrm{C}$ upward in the flint (Fig. 3a) and agate samples (Fig. 3b). However, in 3 flint samples the isolation of $\mathrm{SiOH}$ begins at higher temperatures $\approx 500^{\circ} \mathrm{C}$. These 3 samples also show a gain of molecular water upon heating.

3.1.1.2. Molecular water. No homogenous thermal evolution of the $\mathrm{H}_{2} \mathrm{O}$ band at $5220 \mathrm{~cm}^{-1}$ is observed in the dehydrated state spectra of the 11 flint samples. In dehydrated samples this band expresses the concentration of water strongly retained in closed pores or interstices that cannot be easily evacuated. The band shows a gain of molecular water from $300^{\circ} \mathrm{C}$ upwards for 3 samples (Fig. 4a, these 3 samples are the ones showing the isolation of $\mathrm{SiOH}$ at $500^{\circ} \mathrm{C}$ ) and the loss of almost all $\mathrm{H}_{2} \mathrm{O}$ for 2 samples (Fig. 4b). The remaining flint samples show $\mathrm{H}_{2} \mathrm{O}$ to increase between $250-300{ }^{\circ} \mathrm{C}$ and $400-500{ }^{\circ} \mathrm{C}$ and to be lost above this temperature (Fig. 4c). This heterogeneity might be correlated to internal fracturing (macroscopically observed on the samples) which was very heterogeneous in the 11 flint samples. Some samples did not crack until $600^{\circ} \mathrm{C}$
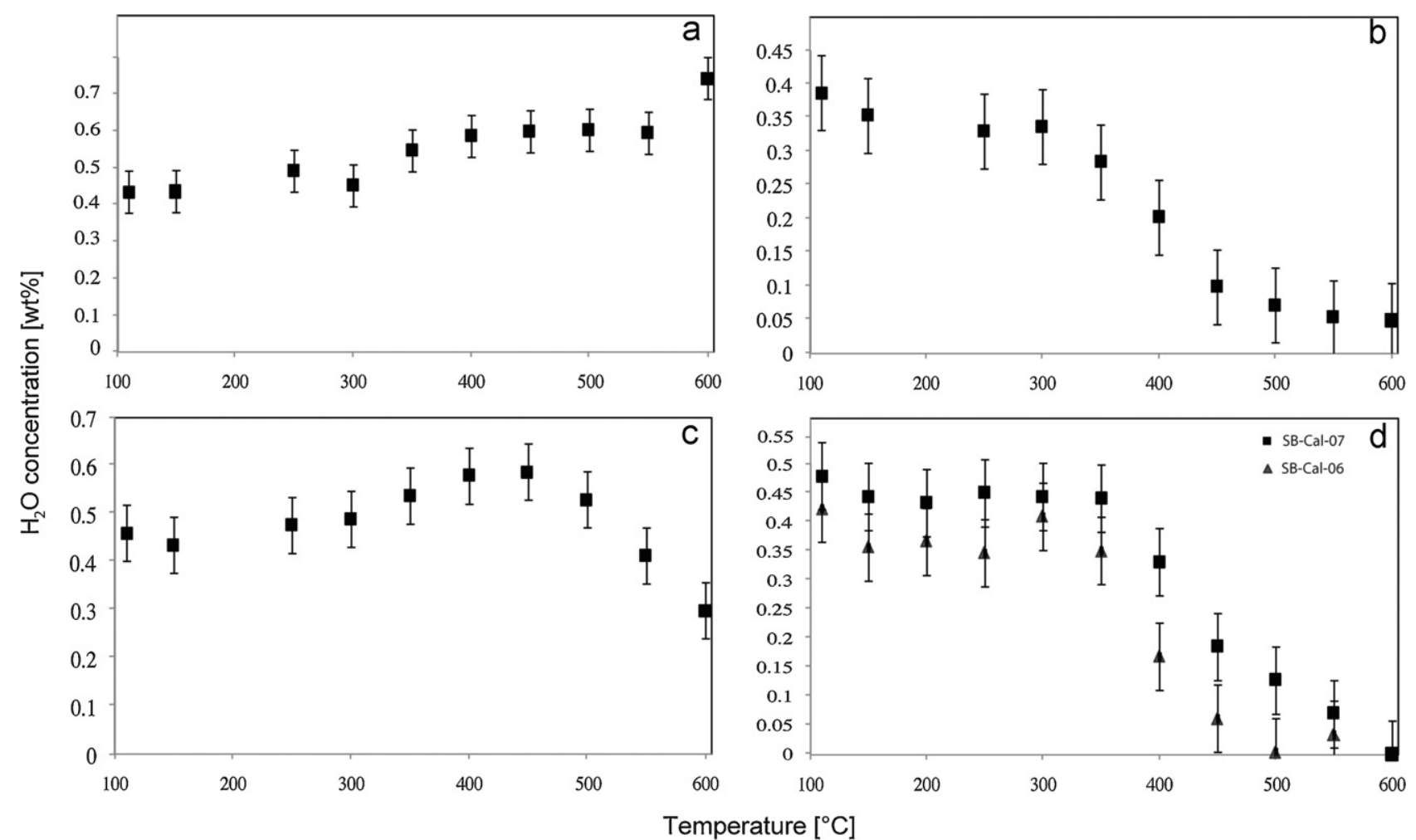

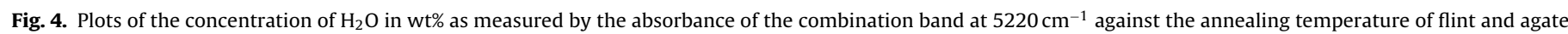

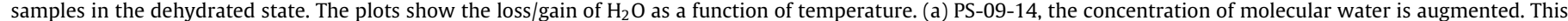

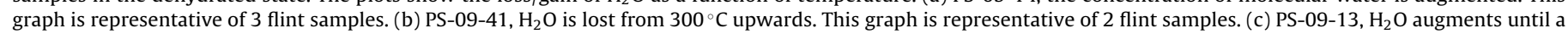

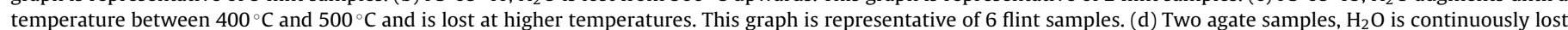
from $300^{\circ} \mathrm{C}$ upwards. 


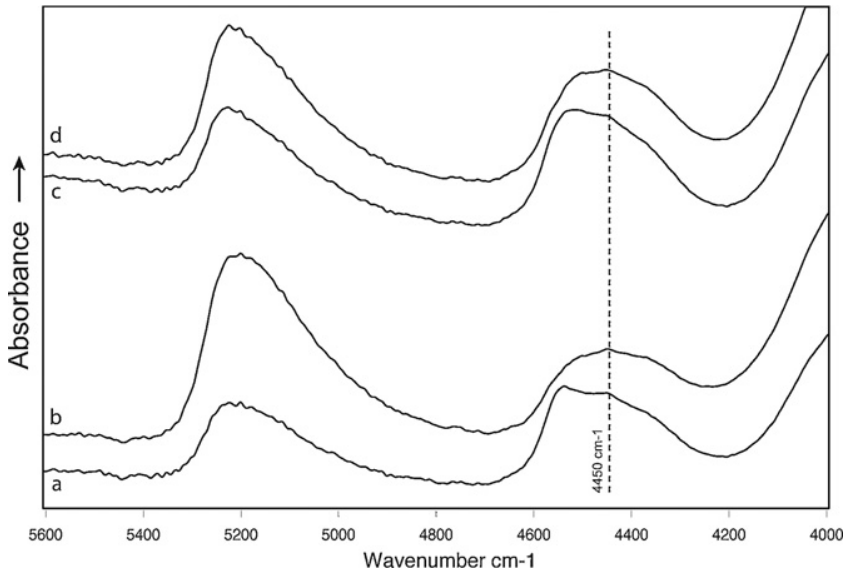

Fig. 5. Room temperature NIR spectra of the $\mathrm{OH}$ region of flint sample PS-S-02 (top) and agate sample SB-Cal-07 (bottom). (a) SB-Cal-07 dehydrated spectrum; (b) hydrated; (c) PS-S-02 dehydrated spectrum; (d) hydrated. The $\mathrm{H}_{2} \mathrm{O}$ band near $5220 \mathrm{~cm}^{-1}$ is more intense in the hydrated state. The $\mathrm{SiOH}$ band near $4540 \mathrm{~cm}^{-1}$ is shaper in the dehydrated state. Spectra displaced vertically and acquired at room temperature.

whereas others turned completely white due to internal fractures. Two of the samples showed almost no fracturing (PS-09-38/41). The $\mathrm{H}_{2} \mathrm{O}$ content of these samples decreases constantly from $300^{\circ} \mathrm{C}$ upwards (Fig. 4b). The two agate samples were also free from fracturing until $600^{\circ} \mathrm{C}$. The plot of their $\mathrm{H}_{2} \mathrm{O}$ content shows continuous loss of water from $350^{\circ} \mathrm{C}$ upwards (Fig. 4d). The 3 samples that gain water over the total temperature interval (Fig. 4a) also show little internal fracturing. The intensity of internal fracturing of the samples might be correlated with the curves showing their $\mathrm{H}_{2} \mathrm{O}$ loss. However, the numerical size of the studied sample does not seem to be sufficient for ascertaining such a correlation.

\subsubsection{Comparison between spectra of hydrated an dehydrated samples}

Fig. 5 shows spectra of a flint (top) and an agate sample (bottom) in their hydrated (b, d) and dehydrated (a, c) states. The $\mathrm{H}_{2} \mathrm{O}$ band is more intense in the hydrated state spectra. The shape of the $\mathrm{SiOH}$ band varies between dehydrated and hydrated states, indicating a different involvement of the silanole content in $\mathrm{H}-$ bonding. The band is sharper in the spectra of dehydrated samples (Fig. 5) and the integrated total area under it is larger (Fig. 6a). The larger area under the band in dehydrated state spectra suggests that the molar absorption coefficient of the SiOH combination band is higher in the absence of H-bonding. Exact quantitative determinations of silanole in chalcedony must take into account the differences between molar absorption coefficients in both states, creating the need for a dehydrated state coefficient. The summit of the band lies at $4547 \mathrm{~cm}^{-1}$ for dehydrated state spectra whereas it is located at $4450 \mathrm{~cm}^{-1}$ in hydrated state spectra. When dehydrated samples are hydrated, the band's summit shifts back to a lower wavenumber, indicating that silanole can form new $\mathrm{H}$-bonds with $\mathrm{H}_{2} \mathrm{O}$ in open porosity. Fig. $6 \mathrm{~b}-\mathrm{d}$ shows three representative examples of the ratio between the values of absorbance at $4547 \mathrm{~cm}^{-1}$ and $4450 \mathrm{~cm}^{-1}$ plotted against the annealing temperature in the spectra of the hydrated samples. This ratio is a measure of the shape of the combination band in the hydrated state and therefore the state of involvement of $\mathrm{SiOH}$ in $\mathrm{H}$-bonding. A value $<1$ indicates that the summit of the band is located at $4547 \mathrm{~cm}^{-1}$, a value $>1$ at $4450 \mathrm{~cm}^{-1}$. This ratio is close to 0.8 for samples heated to temperature less than $300^{\circ} \mathrm{C}$. The temperature at which the ratio shifts above unity lies at $350^{\circ} \mathrm{C}$ for the $11 \mathrm{flint}$ samples (Fig. $6 \mathrm{~b}$ and c) and $400^{\circ} \mathrm{C}$ for the agate samples (Fig. 6d). This temperature lies $50-100^{\circ} \mathrm{C}$ higher than the temperature at which the samples begin to lose silanole. Once the ratio $>1$, the band does not shift back to a lower frequency when it is rehydrated. The SiOH combination band of rehydrated samples that were heated to temperatures
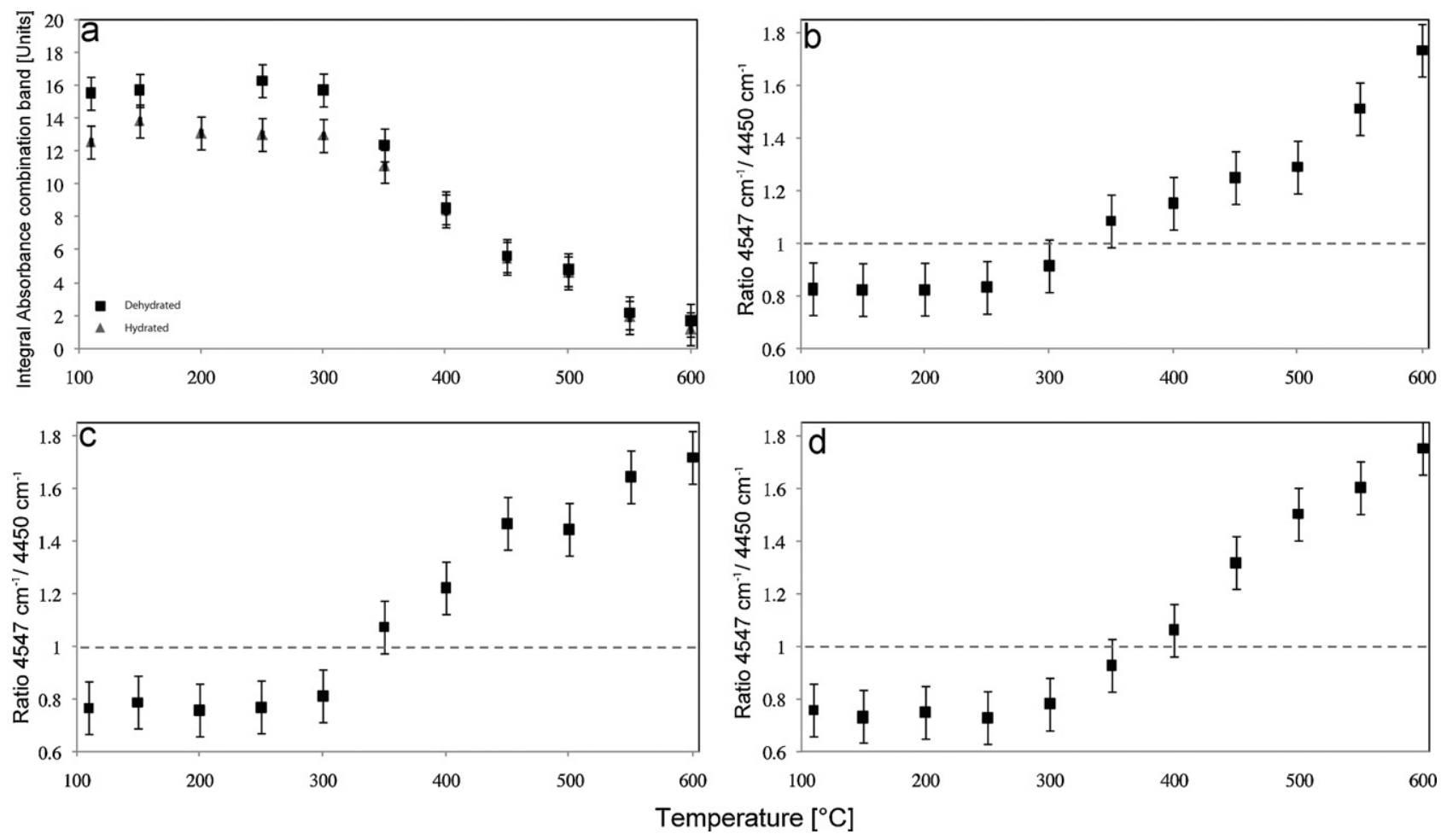

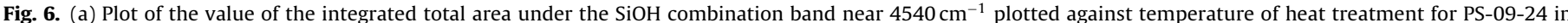

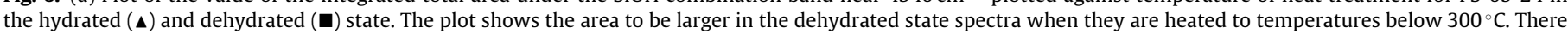

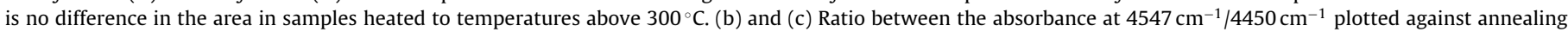
temperature. (b) PS-09-15; (c) PS-09-38 Hydrated state spectra. The ratio increases from $300{ }^{\circ} \mathrm{C}$ upward. (d) $4547 \mathrm{~cm}^{-1} / 4450 \mathrm{~cm}^{-1}$ ratio for agate sample SB-Cal-07. 


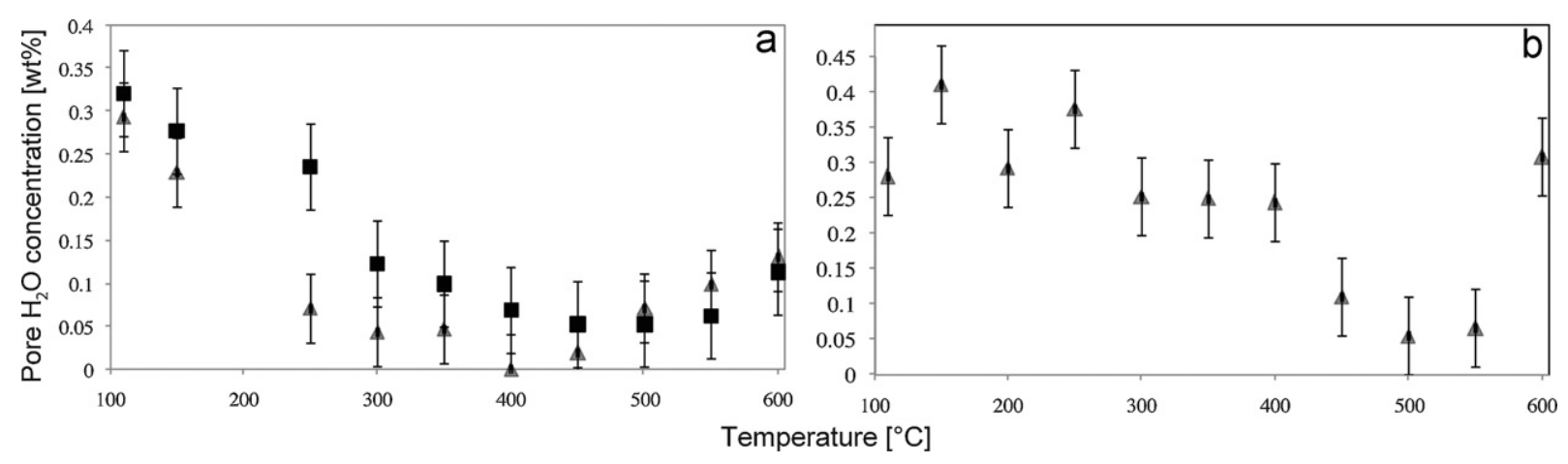

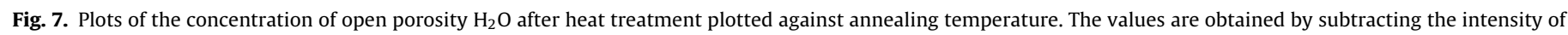

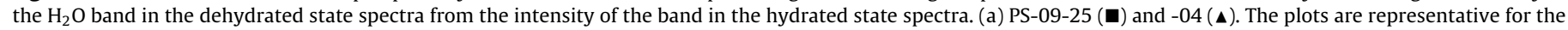
11 flint samples. (b) Agate sample SB-Cal-07.
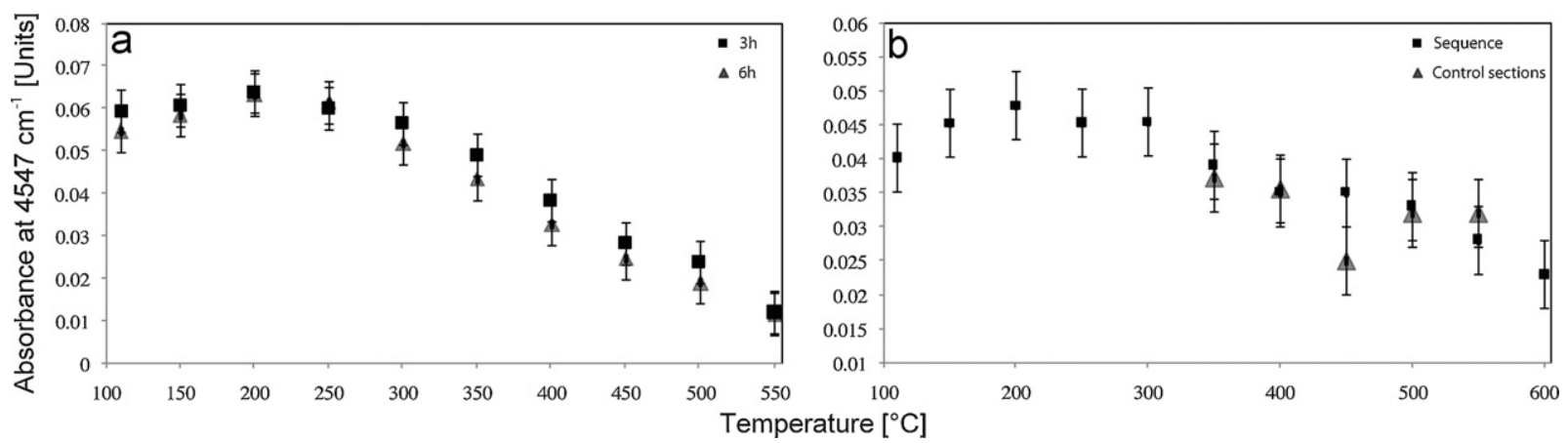

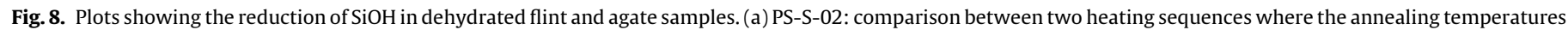

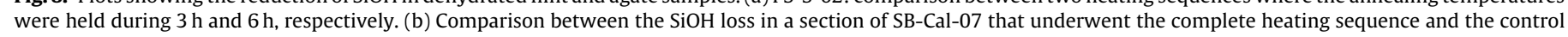
samples. For explanation see Section 2.

above $\approx 300^{\circ} \mathrm{C}$ is identical in shape with the band in the dehydrated state (Fig. 6a) showing that silanole cannot form $\mathrm{H}$-bonds with $\mathrm{H}_{2} \mathrm{O}$ in the open porosity of the samples.

The difference between the value of absorbance of the $5220 \mathrm{~cm}^{-1} \mathrm{H}_{2} \mathrm{O}$ band in the dehydrated state spectra and its value in the hydrated state spectra is proportional to the amount of molecular water [6] that is held in open porosity $\left(\mathrm{H}_{2} \mathrm{O}_{\text {pores }}\right)$ of the samples. Fig. 7 shows the content of open porosity $\mathrm{H}_{2} \mathrm{O}$ after heat treatment and subsequent rehydration, plotted against annealing temperature. The flint samples show constant decrease of the quantity of $\mathrm{H}_{2} \mathrm{O}_{\text {pores }}$ from $150^{\circ} \mathrm{C}$ until $400^{\circ} \mathrm{C}$ to $550^{\circ} \mathrm{C}$ and an increase above this temperature (Fig. 7a). The turning point lies at higher temperatures in agate samples (Fig. 7b) and flint samples with little internal fractures. This turning point between (1) decrease of $\mathrm{H}_{2} \mathrm{O}_{\text {pores }}$ and (2) increase corresponds to the temperature at which the samples exhibit the beginning of internal fracturing determined in macroscopic observations of the sections.

\subsubsection{Assessment of the validity of the experimental protocol}

The amount of silanole lost during heat treatment is the same for sections heated during $3 \mathrm{~h}$ and $6 \mathrm{~h}$ (Fig. $8 \mathrm{a}$ ). The 5 control sections of SB-Cal-07, each heated to a different temperature, lost the same amount of silanole as the section that underwent the complete sequence (Fig. $8 \mathrm{~b})$.

The $4547 \mathrm{~cm}^{-1} / 4450 \mathrm{~cm}^{-1}$ ratio of samples heated during $3 \mathrm{~h}$ and $6 \mathrm{~h}$ are identical throughout the complete annealing sequence within the limits of the calculated error (Fig. 9a). Three of the 5 control sections of SB-Cal-07, each heated to a different temperature, show the ratio to be the same as in the section that underwent the

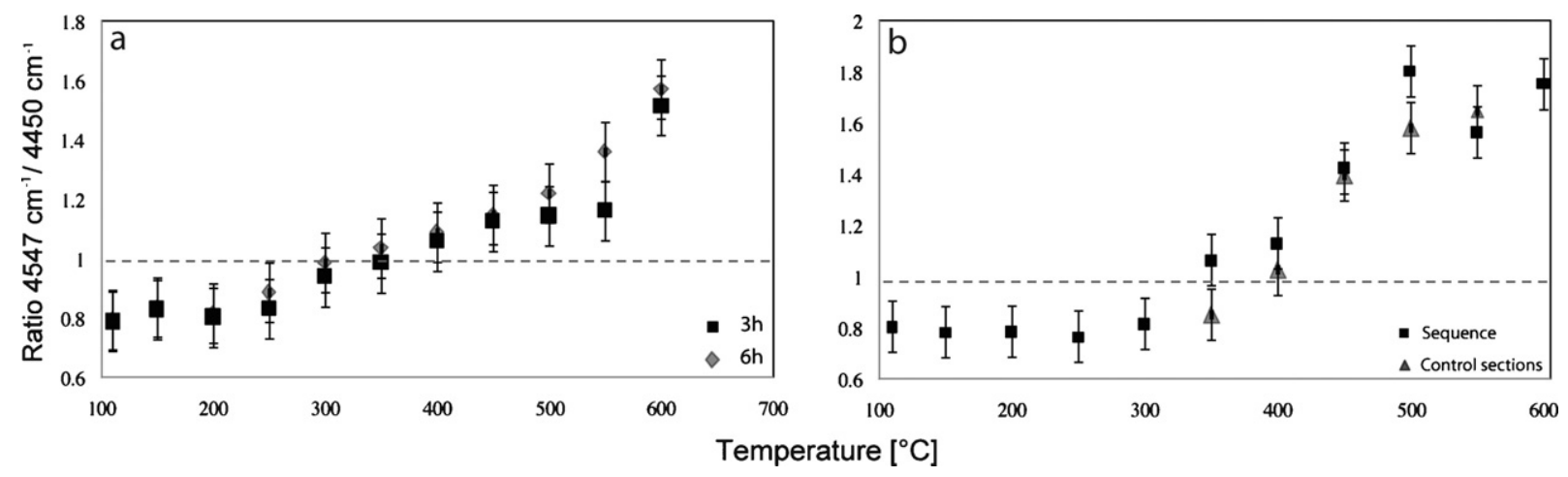

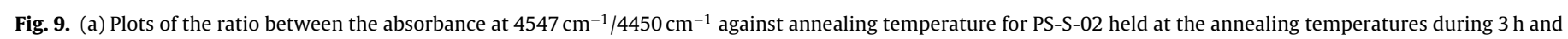
$6 \mathrm{~h}$. (b) Plots of the same ratio for a section of SB-Cal-07 that underwent the complete heating sequence and the control samples. For explanation see Section 2. 

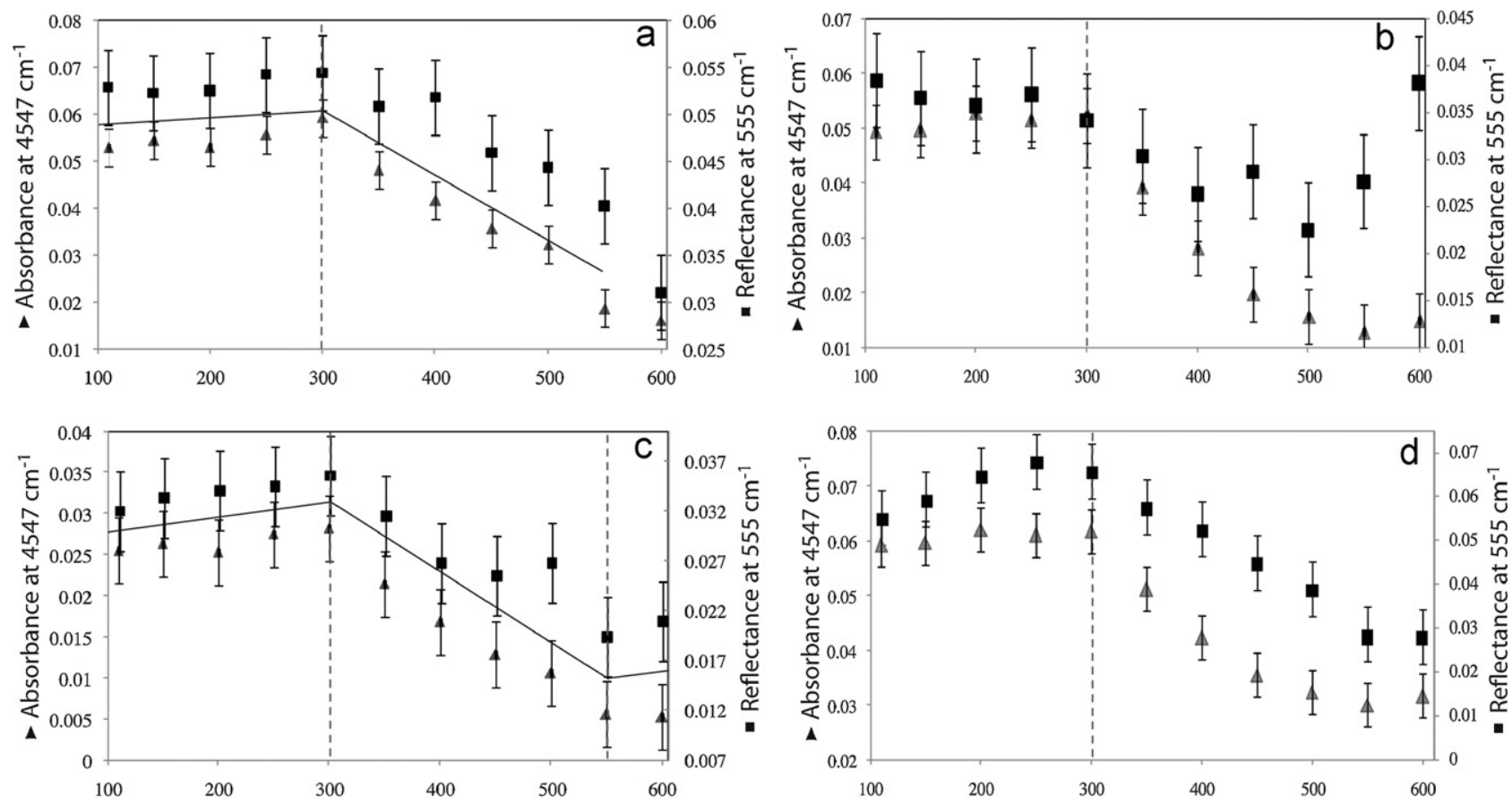

Temperature $\left[{ }^{\circ} \mathrm{C}\right]$

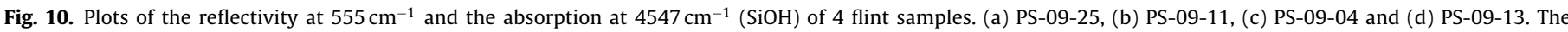

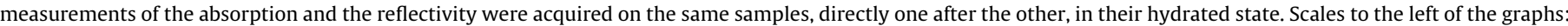

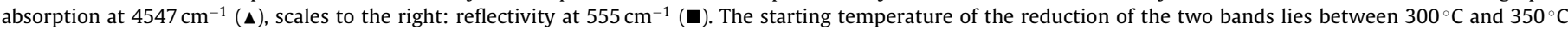
(dotted line) and the identical pace of their reduction shows their correlation.

complete annealing sequence (Fig. 9b). The remaining two control samples show reasonably close values.

\subsection{Mid infrared}

Spectra of the 11 flint samples show a band at $555 \mathrm{~cm}^{-1}$ as already described by Schmidt and Fröhlich [20]. Mid infrared spectra were acquired on hydrated samples. The reflectivity at $555 \mathrm{~cm}^{-1}$ decreases with successive annealing steps from $300^{\circ} \mathrm{C}$ upwards (Fig. 10). The pace of reduction is identical with the pace of reduction of silanole in the samples (Fig. 10) indicating a strong correlation.

\section{Discussion and conclusion}

The 5 control samples show the experimental protocol to be representative of samples heated to a single annealing temperature. Concerning the annealing time, Fukuda and Nakashima [12] found the reduction of silanole to be most intense within the first $50 \mathrm{~min}$ of annealing at $550^{\circ} \mathrm{C}$. Our results confirm that there is no significant difference in the loss of $\mathrm{SiOH}$ between samples annealed during $3 \mathrm{~h}$ and $6 \mathrm{~h}$.

Silanole starts to reduce from 250 to $300^{\circ} \mathrm{C}$ upwards. The appearance of isolated $\mathrm{SiOH}$ coincides with the beginning of the loss. The concomitant beginning of silanole isolation and the reduction of its total concentration suggests that $\mathrm{SiOH}$ is not only involved in $\mathrm{H}$-bonding with $\mathrm{H}_{2} \mathrm{O}$ but also with vicinal $\mathrm{SiOH}$. As already pointed out by earlier works [6-8], the majority of $\mathrm{SiOH}$ in flint and agate samples is lost at $550-600^{\circ} \mathrm{C}$.

The $\mathrm{SiOH}$ concentration in some of the flint and all agate samples seems to increase until $200-250^{\circ} \mathrm{C}$. The apparent augmentation below $200^{\circ} \mathrm{C}$ can be explained by the decreasing influence of molecular water that forms hydrogen bonds with silanole groups.
As seen from the experimental (Section 3.1.2), H-bonding reduces the molar absorption coefficient of the silanole band. Thus, the enlargement of the $\mathrm{SiOH}$ combination band at low temperatures is likely to be caused by the liberation of silanole from H-bonded pore water.

The experiments show molecular water to be held until high temperatures as already pointed out by earlier works $[6-8,12]$. The concentration of $\mathrm{H}_{2} \mathrm{O}$, strongly retained in closed pores, behaves heterogeneously in different samples. Most of the samples gain water over at least a part of the studied temperature interval (Fig. $4 \mathrm{a}$ and $\mathrm{c}$ ). The gain begins at $250-300^{\circ} \mathrm{C}$ indicating the conversion of $\mathrm{OH}$ in silanole to $\mathrm{H}_{2} \mathrm{O}$. This water is held in closed pores, most likely as isolated $\mathrm{H}_{2} \mathrm{O}$ molecules at twin interfaces, and cannot be evacuated. The concomitant reduction of free $\mathrm{Si}-\mathrm{O}$ vibrations, as seen from the $555 \mathrm{~cm}^{-1}$ band [20], above $250-300{ }^{\circ} \mathrm{C}$ suggests the reaction:

$$
\mathrm{Si}-\mathrm{OH} \mathrm{HO}-\mathrm{Si} \rightarrow \mathrm{Si}-\mathrm{O}-\mathrm{Si}+\mathrm{H}_{2} \mathrm{O}
$$

This reaction, creating new bridging $\mathrm{Si}-\mathrm{O}-\mathrm{Si}$, was reported for annealed and hydrothermally treated chalcedony [7,21] and contributes to the closing of the open porosity of the studied samples. Plots showing the reduction of open pores indicate more intense closing from $\approx 300{ }^{\circ} \mathrm{C}$ upwards for some of the samples (indicated by sample PS-09-25 in Fig. 7). However, the analyses suggest that open porosity closure begins at lower temperatures. This apparent low temperature loss of open porosity might be caused by the loss of $\mathrm{H}_{2} \mathrm{O}$, evacuated from very small open pores below $250^{\circ} \mathrm{C}$ and not easily reabsorbed upon rehydration of the samples. The surface of closed pores of small dimensions increases, for $\mathrm{H}_{2} \mathrm{O}$ resulting from reaction (1) that cannot be evacuated through open porosity (Fig. 4a and c) needs place in the chalcedony framework. In some of the samples, newly created $\mathrm{H}_{2} \mathrm{O}$ can be evacuated through open pores or fractures and the molecular water concentration, mea- 
sured through the $\mathrm{H}_{2} \mathrm{O}$ combination band, decreases continuously from $300^{\circ} \mathrm{C}$ upwards (Fig. 4b). This is also the case for the studied agate samples (Fig. 4d), indicating that hydrothermally formed chalcedony contains a more open framework of pores than most of the sedimentary chalcedony, allowing an easier evacuation of $\mathrm{H}_{2} \mathrm{O}$. A more open porosity in hydrothermal chalcedony can also account for the continuous loss of silanole of the agate samples.

The evolution of strongly held $\mathrm{H}_{2} \mathrm{O}$ plotted against temperature shows the moment of internal fracturing (Fig. 4c). Internal fracturing can open up closed pores at temperatures where pressure (caused by $\mathrm{H}_{2} \mathrm{O}$ vapour) in the pores becomes critical. This fracturing causes the turning point at $450{ }^{\circ} \mathrm{C}$ in Fig. 4c. The samples that show continuous water loss also exhibit very little internal fractures indicating a more open porosity through which $\mathrm{H}_{2} \mathrm{O}$ can be more easily evacuated.

Graetsch et al. [7] showed the diminution of the silanole combination band of chalcedony upon heat treatment but reported the band's shape to remained unchanged. This finding cannot be corroborated by the present study. Hydrogen bonding of $\mathrm{SiOH}$ starts to reduce at $250-300{ }^{\circ} \mathrm{C}$ in hydrated state spectra. From $300^{\circ} \mathrm{C}$ to $350^{\circ} \mathrm{C}$ upwards, the presence of open porosity water does not influence the shape of the SiOH combination band any more. Thus, remaining silanole involved in hydrogen bonding is not in contact with the open porosity. This may indicate that the first type of silanole to be evacuated from the samples is surface silanole at the inner walls of open pores. Hydrogen bonding is progressively reduced upon higher temperatures as seen from the $4547 \mathrm{~cm}^{-1} / 4450 \mathrm{~cm}^{-1}$ ratio. This may be due to the loss of silanole that formed $\mathrm{H}$-bonds with vicinal $\mathrm{SiOH}$ at crystal defects and twin interfaces.

Based on the results of the present study, we propose a 4 step model of the transformations sedimentary length-fast chalcedony undergoes upon heat treatment.

(1) The first reaction of the material is the loss of water from open porosity, starting at temperatures below $200^{\circ} \mathrm{C}$.

(2) At approximately $250-300^{\circ} \mathrm{C}, \mathrm{SiOH}$ loss and the healing of defects begin. At defect sites and twin boundaries within the quartz crystallites, molecular water is created from silanole.
(3) Between $300^{\circ} \mathrm{C}$ and $450^{\circ} \mathrm{C}$, the remaining silanole is not in contact with water held in open pores any more. The surface of these open pores is further reduced. The creation of new bridging $\mathrm{Si}-\mathrm{O}-\mathrm{Si}$ bonds and the accumulation of $\mathrm{H}_{2} \mathrm{O}$ within crystallites continue. Isolated $\mathrm{H}_{2} \mathrm{O}$ molecules at twin boundaries and defects attract more $\mathrm{H}_{2} \mathrm{O}$ molecules and new isolated pores, containing molecular water, form.

(4) Between $450^{\circ} \mathrm{C}$ and $600^{\circ} \mathrm{C}$, the concentration of water in closed pores becomes critical and produces high pressure. As a reaction to this, the rock begins internal fracturing, permitting $\mathrm{H}_{2} \mathrm{O}$ trapped in closed pores to be evacuated.

\section{References}

[1] S. Rios, E.K.H. Salje, S.A.T. Redfern, The European Physical Journal B 20 (2001) 75-83.

[2] A. Michel-Levy, C.P.E. Munier-Chalmas, Bulletin de la société minéralogique de France 7 (1892) 159-195.

[3] S.L. Cady, H.R. Wenk, M. Sintubin, Contributions to Mineralogy and Petrology 130 (1998) 320-335.

[4] O.W. Flörke, H. Graetsch, B. Martin, K. Roller, R. Wirth, Neues Jahrbuch für Mineralogie Abhandlungen 163 (1991) 19-42.

[5] G. Miehe, H. Graetsch, O.W. Flörke, Physics and Chemistry of Minerals 10 (1984) 197-199.

[6] O.W. Flörke, B. Köhler-Herbertz, K. Langer, I. Tönges, Contributions to Mineralogy and Petrology 80 (1982) 324-333.

[7] H. Graetsch, O.W. Flörke, G. Miehe, Physics and Chemistry of Minerals 12 (1985) 300-306.

[8] C. Frondel, American Mineralogist 67 (1982) 1248-1257.

[9] C.R. Pelto, American Journal of Science 254 (1956) 32-50.

[10] R.D. Aines, S.H. Kirby, G.R. Rossman, Physics and Chemistry of Minerals 11 (1984) 204-212.

[11] R.D. Aines, G.R. Rossman, Journal of Geophysical Research 89 (1984) 4059-4071.

[12] J. Fukuda, S. Nakashima, Journal of Mineralogical and Petrological Sciences 103 (2008) 112-115.

[13] P. Cordier, J.C. Doukhan, American Mineralogist 76 (1991) 361-369.

[14] H. Scholze, Fortschritte der Mineralogie 38 (1960) 122-123.

[15] K. Langer, O.W. Flörke, Fortschritte der Mineralogie 53 (1974) 17-51.

[16] H.A. Benesi, A.C. Jones, The Journal of Physical Chemistry 63 (1959) 179-182.

[17] J.H. Anderson jr, K.A. Wickersheim, Surface Science 2 (1964) 252-260.

[18] J.H. Anderson jr, Surface Science 3 (1965) 290-291.

[19] R.S. McDonald, The Journal of Physical Chemistry 62 (1958) 1168-1178.

[20] P. Schmidt, F. Fröhlich, Spectrochimica Acta Part A: Molecular and Biomolecular Spectroscopy 78 (2011) 1476-1481.

[21] T. Moxon, S.J.B. Reed, Mineralogical Magazine 70 (2006) 485-498. 